\title{
TAXING ROBOTS AS AN AUTOMATION CONTROL POLICY IN THE INDUSTRIAL REVOLUTION DEVELOPMENT
}

\author{
Nur Arif Nugraha \\ nur.nugraha@pknstan.ac.id, Polytechnic of State Finance STAN
}

\begin{abstract}
The development of industrial revolution in this world has led to massive automation in work areas which can be handled with robots. Therefore, it may result in some potitive and negative consequences. This paper suggests policy ideas on taxing robots to control automation in the industrial revolution development. Using qualitative method with literature reviews, data documentation and data analysis, the author raises some ideas to tax the robot as an automation control policy. This study explores the development of industrial revolution which triggers automation in some administrative and repetitive activities. Then, this paper does not only elaborate scientific journal related to robot tax, challenges, and automation as a result of industrial revolution, but also countries which have implemented this policy, so that taxing robots can be utilized as a policy to control the automation. This research found that there are some opportunities to apply the robot tax to control automation. Furthermore, the author suggested alternatives other than robot tax to deal with automation.
\end{abstract}

Keywords: robots, taxes, automation, policy, industrial revolution

\begin{abstract}
Abstrak
Perkembangan revolusi industri di dunia ini telah menyebabkan otomatisasi yang masif di bidang-bidang pekerjaan yang dapat ditangani dengan robot. Hal ini dapat mengakibatkan beberapa konsekuensi positif dan negatif. Penelitian ini mengusulkan gagasan kebijakan perpajakan robot untuk mengendalikan otomatisasi sehubungan dengan perkembangan revolusi industri. Dengan menggunakan metode kualitatif dengan studi kepustakaan, dokumentasi data dan analisis data, penulis mengajukan beberapa ide untuk memajaki robot sebagai kebijakan pengendalian otomatisasi. Studi ini mengeksplorasi perkembangan revolusi industri yang memicu otomatisasi dalam beberapa kegiatan administratif dan aktivitas yang berulang. Paper ini tidak hanya mengelaborasi beberapa referensi ilmiah pajak robot, otomasi akibat revolusi industri dan tantangannya, namun negara-negara yang telah menerapkan kebijakan ini, sehingga pemajakan robot ini dapat dimanfaatkan sebagai kebijakan untuk mengendalikan otomasi. Penelitian ini menemukan bahwa ada beberapa peluang untuk menerapkan pajak robot untuk mengendalikan otomatisasi. Selanjutnya, penulis menyarankan alternatif selain pajak robot untuk menangani otomatisasi.
\end{abstract}

Kata Kunci: robot, pajak, otomasi, kebijakan, revolusi industri

\section{INTRODUCTION}

The 4th Industrial Revolution is a crucial industrial transformation involving innovative processes in technology and communications. The Industrial Revolution does not only accelerate the development of productivity and materials, but also presented its own challenges for individuals, the economy, society, culture, and politics (Lin, 2017). United States, South Korea, Germany, Japan, and China are some leading countries in the 4th Industrial Revolution (Davis, 2016). Indonesia continues to develop itself in pursuing technological developments in this 4th Industrial Revolution. Many private companies are starting to use technology concepts to maximize their business potential, especially artificial intelligence.

The term "4th Industrial Revolution" was coined by the founder of the World Economic Forum, a former professor named Klaus Schwab. Schwab wrote a book entitled Fourth Industrial Revolution to describe an era marked by a technological revolution that blurs the lines between the physical, digital, and biological fields. Technologies like artificial intelligence, autonomous vehicles, or the Internet of Things are becoming embedded in our daily lives and even, our bodies. Schwab first presented his vision of the 4th Industrial Revolution at the annual meeting of the World Economic Forum (Davos, 2016). The 1st Industrial Revolution began in Great Britain around 1760 and spread to Europe and North America until the early 1800s. This is supported by the great invention of the steam engine and 


\section{EDUCORETAX}

Volume 1 No. 3, September 2021

the railroad. The result of this invention is a new manufacturing process, the creation of factories, and a rapidly growing textile industry (Schwab, 2016).

Since the late 1800s, the 2nd Industrial Revolution began and was marked by mass production and new industries such as steel, oil, and electricity (Schwab, 2016). The light bulb, telephone, and internal combustion engine were some of the major inventions of this era. The 3rd Industrial Revolution, sometimes known as the Digital Revolution, took place in the second half of the twentieth century (Schwab, 2016). In just a few decades, the invention of semiconductors, personal computers, and the internet could be enjoyed by many people. The main difference between the 3rd and 4th Industrial Revolutions is that technology is increasingly integrated into human life and technological change is happening faster than ever. Consider this can be illustrated by the pace of technological development and adaptation that humans have made. It took 75 years for 100 million users to adopt the phone but Instagram got 100 million users in just two years (Gould, 2015).

The purpose of this research is to answer four questions. Firstly, what are the risks of automation to jobs in the 4th Industrial Revolution? Secondly, what are the challenges facing the robot tax idea? Thirdly, what are the methods that can be used in the robot tax? Finally, what are the alternative solutions to the robot tax in the face of automation?

The taxation system faced new challenges as a result of the 4th Industrial Revolution. Globalization and new technologies can affect the way a country's tax system or a particular tax is designed and managed. In addition to facilitating business in jurisdictions, digital technology enables consumers to access products and services anywhere in the world. This creates challenges in terms of collecting the appropriate amount of tax (OECD, 2014, p. 125).

The main goal of taxation of robots and automation-led processes is to finance the training costs required for those who lose their jobs to adapt to new business areas. Taxes can also compensate for the decrease in tax revenue the government collects on wages. For Bill Gates (2018), another problem addressed by the robot tax is slowing down the pace of investment in robots and helping people overcome their anxiety about the encroachment of technology into the workplace (Dunlop, 2017). Therefore, robot tax should be one of the important agendas of the international world, especially developed countries because it has an impact on various parties and needs harmony in its manufacture. However, there are not many research conducted by academics or professionals. Shortly, this topic should be an important moment for various parties to review and reassess the existing tax concepts, methods, and objectives.

\section{LITERATURE REVIEW}

\section{Essential Products of the 4th Industrial Revolution}

The 4th Industrial Revolution era was marked by the role of various important technologies including Artificial Intelligence, Internet of Things, Blockchain, and Cloud Computing (Schwab, 2016). Artificial intelligence is the science of making smart machines, using algorithms to enable computers to solve problems that were previously only solved by humans (McCharty, 2007). This intelligence has empowered search engines, online shopping recommendations, and digital assistants (Schwab, 2016). Radiologists can use artificial intelligence to calculate the exact shape and volume of tumors, whereas aastronomers use this intelligence to find and evaluate exoplanets in distant solar systems. The scope of artificial intelligence is believed to be unlimited so that it becomes the "brain" and benchmark of every technological transformation from ancient times to the future.

The Internet of Things (IoT) is a giant network of connected devices sharing information (Pearlman, 2019). These devices collect and share data about how the device is used and the environment in which the device is operated. Everything is done using sensors embedded in 


\section{EDUCORETAX}

Volume 1 No. 3, September 2021

each physical device. These devices can be mobile phones, electrical appliances, barcode sensors, traffic lights, and almost anything that people find in everyday life (Pearlman, 2019). These sensors continuously transmit data about the working state of the device. Data transmitted from various sensors is sent to the IoT platform. The IoT platform integrated data collected from multiple sources. Further analysis is carried out on valuable data and information processed as needed (Pardes, 2020).

Cloud computing is the delivery of computing services including servers, storage, databases, networks, software, analytics, and intelligence over the internet to offer faster innovation, flexible resources, and economies of scale (Microsoft Azure, 2020). Organizations of every type, size and industry use cloud computing for activities such as data backup, data disaster recovery, and big data analysis. Financial services companies use cloud computing to strengthen fraud detection and prevention (Lakshminarayanan, 2019). With cloud computing, organizations or companies can save money and increase profits, which they put back into the business to increase the number of employees, increase wages and encourage innovation (Olavsrud, 2013).

Blockchain is an open and distributed system of large books or records that can record transactions between two parties efficiently and in a verifiable and permanent way (Iansiti and Lakhani, 2017). That way no one can fool the system by editing the records because everyone who uses the system will see it. Blockchain stores information across a network of private computers, making it not only decentralized but also distributed (Reiff, 2020). Blockchain uses a form of mathematics called cryptography to ensure that records cannot be falsified or altered by others (Rosic, 2016).

\section{Initiatives of Some Countries in the 4th Industrial Revolution United States of America}

The United States has a special initiative to improve the robot infrastructure in its country. This initiative is named the National Robotics Initiative (NRI) which was launched in 2011 through the National Science Foundation (2019). Currently, the program has been late being updated to NRI-2.0. The NRI program seeks research on the basic science, technology, and integrated systems needed to achieve the vision of "Ubiquitous Collaborative Robots". The goal of NRI is to accelerate the development and use of co-robots, robotic systems, and devices that work cooperatively as partners with the crowd. The NRI did not only invest in the fundamental research for future robots, but also advance the capability of such systems and encourage existing and new research communities to focus on innovative application areas. An important role of computing community was the formulation of this initiative through its work on two main products. First, A Roadmap for U.S. Robotics - From Internet to Robotics, which was developed by more than 100 experts from industry and academia as part of the vision of the Computing Community Consortium (CCC). Second, Science and Technology (PCAST), Designing a Digital Future: Federally Funded Research and Development in Networking and Information Technology, which was issued by the President's Council of Advisors predicts that the impact of $R \& D$ in robots will have dramatic benefits for productivity and sustainable economic growth (Jahanian, 2011).

Japan

Robotic technology has the potential to solve social challenges, such as solving labour shortages and increasing productivity in various sectors as birth rates fall, society ages, and the aging population shrinks. Taking these challenges into account, the revised Japan Revitalization Strategy 2014 includes a "New Industrial Revolution Driven by Robots" which consists of utilizing robotic technology to improve Japanese productivity, increase the earning power, and raise wages. To achieve this revolution, Japanese Government formed the Robot Revolution Realization Council in September 2014. To follow up the initiative, Japanese Government 


\section{EDUCORETAX}

Volume 1 No. 3, September 2021

developed strategies and action plans by sectors towards the realization of the robot revolution called Japan's Robot Strategy. Japan achieved this revolution by promoting the following three pillars. First, fundamental improvement of Japan's robotic manufacturing capabilities so as to make Japan a centre for robot innovation in the world. Second, utilization and deployment of robots throughout Japan, named efforts to showcase robots to the world, aiming to achieve the society with the highest utilization rate of robots in the world. Finally, the development of Robot Revolution expects worldwide dissemination, which aims to formulate business rules on the interconnection premises between autonomous robots and data utilization, to standardize Japanese robot technology globally, and to disseminate the approach to a wider area (The Headquarters for Japan's Economic Revitalization. 2015).

\section{South Korea}

The South Korean government formed a new team at the Ministry of Trade, Industry and Energy in December 2005 to be in charge of the robot industry (Kim, 2018). In 2008, a series of government actions and initiatives, including the enactment of the Intelligent Robot Development and Distribution Promotion Act, increase Korea's visibility to build industrial robots. The government formulated a national plan for the same purpose in 2009 and 2014 with the same legal product. Since then, South Korea has also focused on improving the robot industry by expanding the demand base for robots through market creation and building the right infrastructure (Kim, 2018). In February 2018, based on Kim Sang-mo (2018), the government released a new development strategy for the smart robot industry along with four action plans aimed at increasing the competitiveness of the industry and creating a "smart country" where humans and robots coexist. The action plan calls for accelerated market expansion with collaborative robots and service robots while increasing industry supply and demand capabilities through support for spare-parts development and system upgrades.

\section{Indonesia}

In 2018, the Ministry of Industry has compiled the "Making Indonesia 4.0" initiative to implement the 4IR (4th Industrial Revolution) strategy and Roadmap in Indonesia. This Roadmap involves various stakeholders, ranging from government institutions, industry associations, business actors, technology providers, as well as research and educational institutions. Through the commitment and active participation of various stakeholders, including ministries and other government agencies, partnerships with private parties and leading industry players, investors, educational institutions, research institutions, the government believe the Making Indonesia 4.0 blueprint can be carried out successfully. Indonesia is committed to building a strong manufacturing industry. To revitalize the manufacturing industry, Indonesia is committed to accelerating the implementation of 4IR. The Making Indonesia 4.0 initiative provides great potential to multiply labor productivity, so as to increase global competitiveness and increase global export market share. Higher exports can create more jobs, so that domestic consumption becomes stronger and Indonesia can become one of the top 10 world economies. (Ministry of Industry of Republic of Indonesia, 2018).

Figure 1 below shows that the level of robot density to workers. This statistic describes the number of robots per 10,000 industrial workers. In 2018, Singapore was ranked first with a total of 831, beating South Korea which in 2016 was ranked first. After Singapore and South Korea, Japan and Germany followed with more than 320 numbers. One of the countries of concern is China, which is sped up with the ambition to continue to increase the number of robots with its program, Development Plan of the Robot Industry 2016-2020 (International Federation of Robotics, 2020). 


\section{EDUCORETAX}

Volume 1 No. 3, September 2021

\section{Figure 1 Robot density ratio}

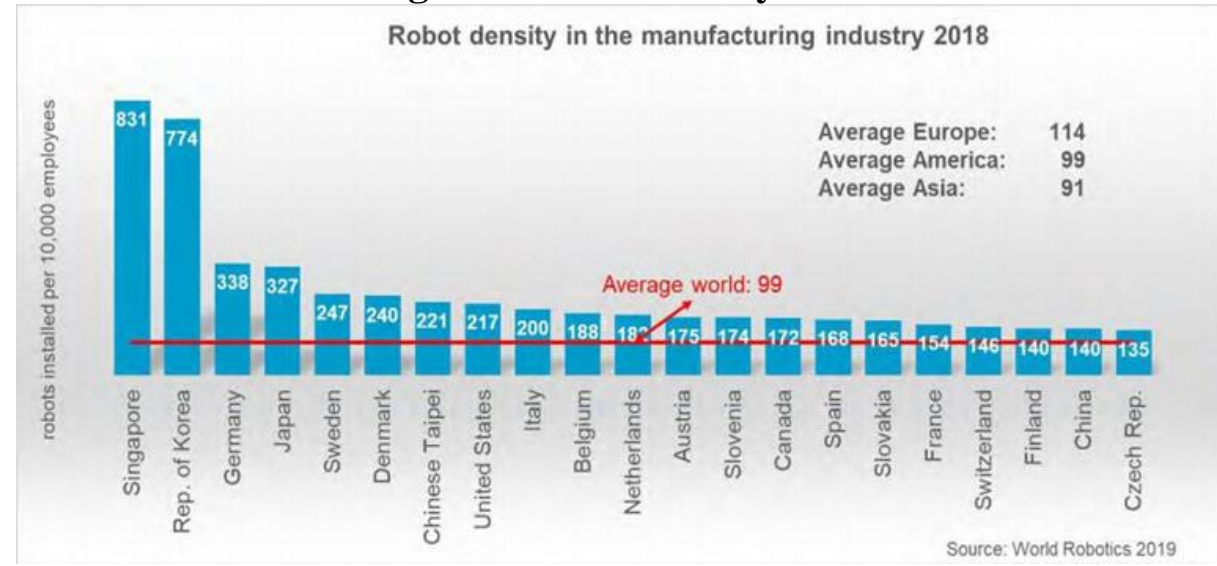

Source: International Federation of Robotics 2019

\section{Prediction of The Impact of Work Automation and Government's Readiness in Adopting Technology}

Based on additional data collection and interpretation by the MIT Technology Review of studies and opinions conducted by Metra Martech, Forrester, Gartner, World Economic Forum (WEF), International Federation of Robotics (IFR), Thomas Frey, Science Alert, McKinsey, PwC, Bank of England, Institute for Public Policy Research (IPPR), and OECD, each agency did not provide similar results on the size of the impact of automation. The 2013 Oxford Study entitled "The Future of Employment: How Susceptible are Jobs to Computerisation?" which mentioned that $47 \%$ of jobs in the United States had a high risk of being exposed to automation in the next few decades, the OECD Study entitled The Risk of Automation for Jobs in OECD Countries which indicated that $9 \%$ of jobs in the 21 member countries of the organization had automation potential, and 2018 McKinsey The report, titled Jobs lost, jobs gained: What the future of work will mean for jobs, skills, and wages, says that 400-800 million jobs worldwide are likely to be automated by 2030 .

Government AI Readiness Index 2019 is an index that shows the government's readiness to take advantage and benefit of AI in operational activities and public services. This index was created by Oxford Insight and the International Development Research Centre. Countries that are in the top five according to this index include Singapore $(9,186)$, United Kingdom $(9,069)$, Germany (8,810), United States $(8,804)$, and Finland (8,772). Indonesia is ranked 57 out of 194 countries with a value of 5,420 .

Figure 2 Robot stock development (2000-2015)

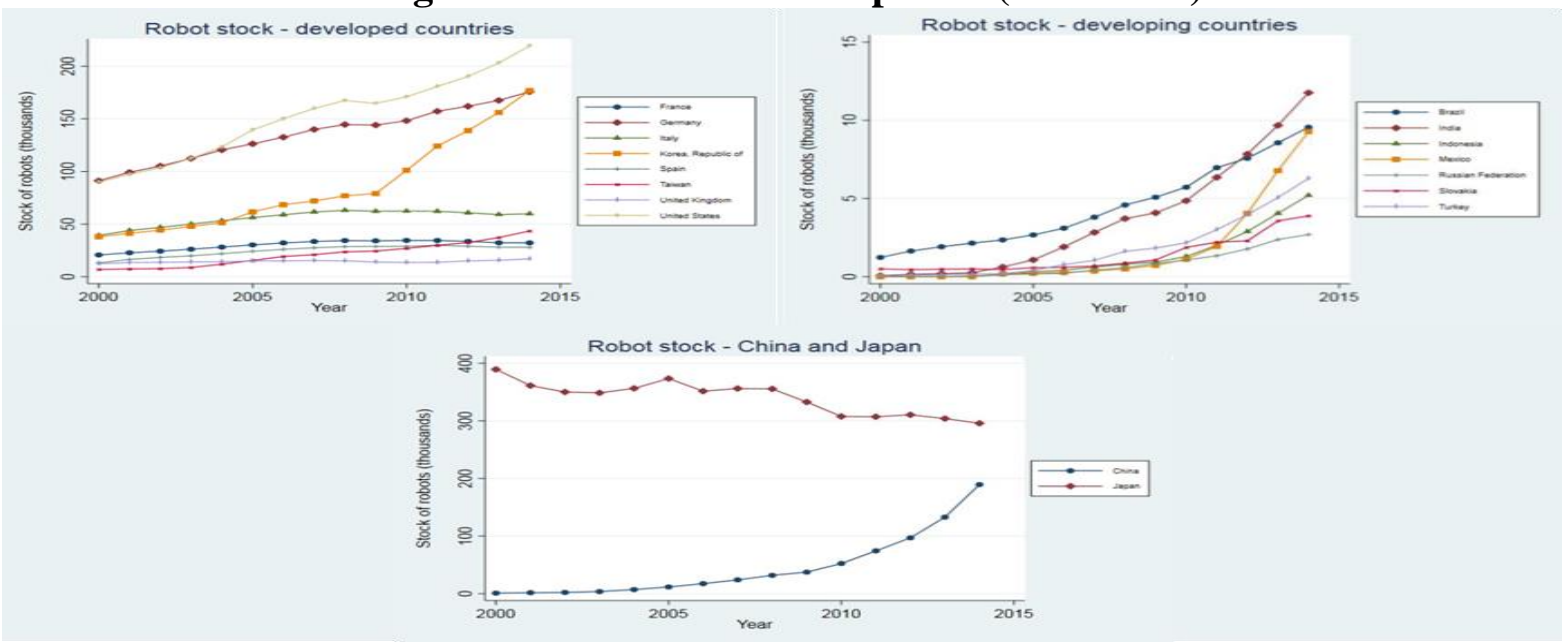

Source: International Federation of Robotics 2016 


\section{EDUCORETAX}

Volume 1 No. 3, September 2021

Figure 2 above presents the development over time the number of robots in various countries. Japan and China are on separate charts because of their extreme scores within their group. Among developed countries, after Japan, South Korea emerged as one of the first investors in robots next to the United States and Germany, while Italy showed a downward trend. Regarding developing countries, India, Brazil and Mexico show the highest stock levels, followed by a mix of Asian and European countries and Russia. China stands out as a country that has installed more robots than any other country in the world and is expected to develop even more, given the planned targets of 100,000 robots per year by 2020 .

\section{Significant Events Related to Robot Tax European Civil Law Rules on Robotics}

With a view to developments in robotics and artificial intelligence, the Committee on Legal Affairs considers it is time for the European Union to take action with respect to the legal and ethical issues raised by this new technology. A working group was established in 2015 with the main objective of drafting the European Union's (EU) civil law code in this area. While respecting the EU's initiative rights, on May 31, 2016 this group submitted a draft report which set out a series of recommendations on civil law rules on robotics. This draft included a motion for the EU Parliament resolution, accompanied by detailed recommendations for the legislative proposal and an explanatory statement indicating that the purpose of the legal instrument is to settle down general and ethical principles of the development of robots and artificial intelligence. The European Civil Law on Robotics consists of several components; General Considerations on Robots, Liability in Robotics, and Ethical Principles to Develop in Robotics. Several points of concern in this proposal are the classification and definition of smart and autonomous robots and the granting of "electronic personhood" status which made them to have a status of legal subjects (Nevejans, 2016).

\section{South Korea's "Robot Tax"}

In 2017, in a planned revision of the tax law, the Government led by Moon Jae-in said it would reduce the tax reduction benefits that the previous government provided companies for infrastructure investments aimed at increasing productivity (Yoon, 2017). At that time, companies that have invested in industrial automation equipment are eligible for corporate tax deductions. Companies can deduct between 3\% and $7 \%$ according to regulations from the investment value against their corporate income tax. These rates vary based on the size of their business. This proposal proposes reducing the percentage of incentives to 2\% (Yoon, 2017). While this is not a direct tax on robots as there are no new costs arising from the proposal, it made South Korea the first country to act on automation in the world of taxation.

\section{Previous Studies}

There were three most relevant studies to this research. First, "Optimal Taxation of Robots" by Thuemmel (2018), which focused on studying robot tax and optimal labour wages in Stiglitz Model and US Model. Second, "Should Robots Pay Taxes? Tax Policy in the Age of Automation" by Abbott and Bogenschneider (2018), which emphasized on problems arised because of automation. The US tax policy supported automation, and the introduction of automation tax. Third, "A Note on Automation Stagnation, and the Implication of a Robot Tax" by Gasteiger and Prettner (2017), which discussed long-term impact on automation towards Overlapping Generation Model and The Effect of Robot Tax on Economic Growth.

Based on the results of a study conducted by Thuemmel (2018), in his model, robots replaced routine work and complement non-routine work. Thuemmel pointed out that while optimal for distorting the use of robots, robots can be taxed or subsidized. The robot tax exploited the general equilibrium effect to suppress the wages distribution. Wage compression reduces income tax distortions from the labour supply. In the calibrated model, the optimal 


\section{EDUCORETAX}

Volume 1 No. 3, September 2021

robot tax for the US was positive and generated small welfare gains. When the price of robots fell, inequality rose, but the taxes on robots and their welfare impact were negligible.

In their research conducted by Abbott and Bogenschneider (2018), they argued that the existing tax policy in the United States should be changed. Systems must be at least "neutral" as between robots and human workers, and automation must not reduce tax revenue. This could be achieved through some combination of deducting corporate taxes that are not permitted for job automation, creating an "automation tax" that reflects existing unemployment schemes, providing an offset to tax preferences for human workers, levying a corporate self-employment tax, and increasing corporate tax rates. The current tax system was seen as incentivizing automation even in cases it is inefficient. Those were unintended results of a system designed to tax labour rather than capital.

In their research focusing on the impact of economic growth, Gasteiger and Prettner (2017) argued that while automation implies a constant return to capital in the OLG class model, automation did not have the potential to lead to positive long-term growth. The reason was that automation depressed wages, which were the only source of investment due to the model demographic structure. This result contradicted to the effect of automation in representative agency settings. Positive long-term growth was possible because agents can invest from their wage income and asset income. They also analysed the effect of robotic taxes on automation in policy debates and showed that it could increase the capital stock and income per-capita in a steady nation. However, robot taxes could not push towards positive long-term growth.

\section{METHOD}

This research applied the qualitative method with literature reviews on related theme in robot tac. The data collection method describes the method used by the author in collecting research data. The definition of research methods according to Sugiyono $(2015$, p. 2$)$ states that research methods are scientific ways to obtain data with certain goals and uses.

This paper applies secondary by studying data documentation in extensive mind (Bowen, 2009). Documents are a form of legislations as well as their technical implementation rules. The source document is scientific journal articles in robot taxes-related themes accompanied by the Minister of Finance Regulation. The data source will go hand in hand with other government regulations as well as various media releases.

Data analysis will be conducted using interactive models of data analysis proposed by Miles and Huberman (1994), as presented in Figure 3 below. The author will use the model based on accumulated knowledge and experiences in taxation and state financial to examine various sources then interpret to obtain the result of study and conclusions. This means is crucial to provide a comprehension of the context and its socio-historical links (Yanow 2000; Yanow 2007; Glynos et al., 2009).

Figure 3. Interactive Data Analysis Model

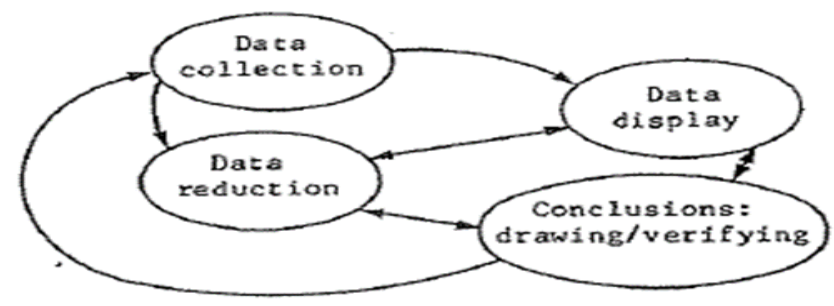

Sumber: Miles and Huberman, 1994

Nazir (2014) stated that literature study is a data collection technique by conducting a review study of books, literatures, notes and reports that have to do with the problem being solved. In the library method, the authors collect data and information through related literacy, 


\section{EDUCORETAX}

Volume 1 No. 3, September 2021

such as the impact of work automation, phases taken in the formulation of a robot tax, arguments for and against the existence of a robot tax, and various methods that can be used in the robot tax.

\section{RESULT AND DISCUSSION \\ Robots and Artificial Intelligence}

The first use of the word "robot" occurs in a drama about human-shaped machines built to work on factory assembly lines and who rebel against their human masters. These machines get their name is Czech for forced labour in R.U.R. (Rossum's Universal Robots), written by Czech playwright Karol Capek, in 1921. The word "robot" was also coined by an author. Russian-born American science fiction writer Isaac Asimov first used the word in 1942 in his short story "Runabout". Asimov has a much brighter and more optimistic opinion about the role of robots in human society than Capek. Asimov also proposed a Law of Robotics which contains three laws. First, robots must not injure humans or, in the absence of action, allow humans to be injured. Secondly, robots must obey orders given by humans unless such orders would be contrary to the first law. Thirdly, robot must protect its own existence as long as such protection does not conflict with the first or second law.

Over time, robots evolved from George Devol's robotic arm in 1954, a machine that could only move objects in a fixed path to robots that could move, see, hear, speak, and be creative like Ai-Da, a human robot that could paint. The evolution of the robot is certainly influenced by the development of AI as the centre of all modern robot operating systems and the benchmark of the technological revolution. AI was first introduced by John McCharty in 1955. According to McCharty (2007), AI is defined by scientific proses to create intelligent devices, particularly smart computer programs, which was linked to the identical assignment of computer use to conceive the brilliance of human. Artificial Intelligence can also be regarded as computer systems which capable of accomplishing tasks that involve thinking processes such as reasoning, planning, learning, and self-correction. The fundamental difference between Arrtificial Intelligence (AI) and Human Intelligence (HI) is as follows:

Table 1 The Differences between AI and HI

\begin{tabular}{|l|l|l|}
\hline \multicolumn{1}{|c|}{ Difference } & \multicolumn{1}{c|}{ Artificial Intelligence } & \multicolumn{1}{c|}{ Human Intelligence } \\
\hline Origin & Human innovation & Since the human birth \\
\hline Speed & Faster & Slower \\
\hline Decision Making & More objective & More subjective \\
\hline Result & More accurate & Less accurate \\
\hline Efficiency & More efficient & Less efficient \\
\hline Adaptability & Needs longer time & Needs shorter time \\
\hline Multitasking & Less multitasking & More multitasking \\
\hline Function & Optimazion & Can innovate \\
\hline Phase & Digital & Analog \\
\hline
\end{tabular}

Source: Processed by the Author

In its application, AI can be classified according to how it works and its use. Based on how it works, AI is divided into rule-based AI and machine learning. Rule-based AI is the most basic form of AI. In this type, AI does not yet have the ability to learn independently and is programmed entirely by humans from input, process, to output. Machine learning is an AI that already has the ability to learn independently. This type of AI can already process and learn the patterns given to it. Artificial Intelligence can be classified into computer vision, natural language process (NLP), speech, and robotics. The products of computer vision are augmented reality (AR) and virtual reality (VR). The products of NLP and speech are intelligent personal assistants such as Google's Google Assistant, Apple's Siri, and Amazon's Alexa. Examples of 


\section{EDUCORETAX}

Volume 1 No. 3, September 2021

products from robotics are Ai-Da, a human robot that can paint, and Sophia, a human robot that can do various things like humans in general.

The development of $\mathrm{AI}$ is supported by its self-learning system called machine learning (ML). Mitchell (1997) defines machine learning as a computer program that learns from the experience $(\mathrm{E})$ if the performance $(\mathrm{P})$ in doing the task $(\mathrm{T})$ increases because of the experience (E). The source of robot experience is data. This concept is similar to independent learning carried out by humans. The learning carried out by AI is divided into several parts, namely supervised learning, unsupervised learning, semi-supervised learning, and reinforcement learning. Supervised learning is a learning method with data labelled by humans. Humans still have full control in sorting and classifying the data. In unsupervised learning, AI is driven independently to sort and group the data needed in the process to achieve its goals. Humans do not exercise control and supervision in this system. Semi-supervised learning is a combination of supervised learning and unsupervised learning. Reinforcement learning brings AI closer to human life with the characteristic of learning with a reward and punishment system.

From an economic point of view, the current AI technology will make the prediction process cheaper (Agrawal et al., 2018). This is because today's AI technology is basically machines that are very effective at predicting things. Computer vision is very effective at predicting objects in photos or videos, while NLP is very effective at predicting what someone's speech means. The cheapness of the prediction process will make some things more valuable and more expensive, such as data, decision making, and action. While there will be things that become worthless, in this case an example would be the manual prediction process by humans. AI makes some tasks automated.

\section{Automation and Human Work}

Automation, robotics and artificial intelligence are indispensable components especially in the 4th Industrial Revolution. The definition of automation in the KBBI is the replacement of human labour with machine power that automatically performs and manages work so that it no longer requires human supervision (in industry and so on). Whereas in the Oxford English UK Dictionary, automation is the use of machines and computers to do work that was previously done by people. From these two definitions, the author defines automation as an adaptation process carried out by technology to human tasks and work, helping or replacing human roles in everyday life.

Industrial automation has been developing since the 1st Industrial Revolution with the steam engine became the most famous product. It created new and large economies in many parts of the world. The work which was initially relied on human and animal power at that time, was replaced by the steam engine which made a massive market expansion due to its efficiency. Automation has a clear impact that the role of humans is replaced by machines or robots, which can them lose their jobs. Technology is slowly replacing the role of humans in their daily lives, especially in repetitive jobs and require physical works. However, automation also generates new jobs from every industrial opportunity as well as jobs related to the machines or robots. Experts continue to find out whether the impact this automation has on human work as a whole is for the better or not. This impact is also considered by the government in making policies to lessen the overall negative impact.

\section{Analysis of Result Risks of automation to labour supply}

Many studies show that automation causes massive changes in the level and structure of work. Studies on the prediction of jobs lost and new jobs emerging from automation agree that automation is shifting people to fill jobs that require low-level skills and creating new jobs with higher qualifications and new industries. 


\section{EDUCORETAX}

Volume 1 No. 3, September 2021

Figure 4 Impact of automation on work

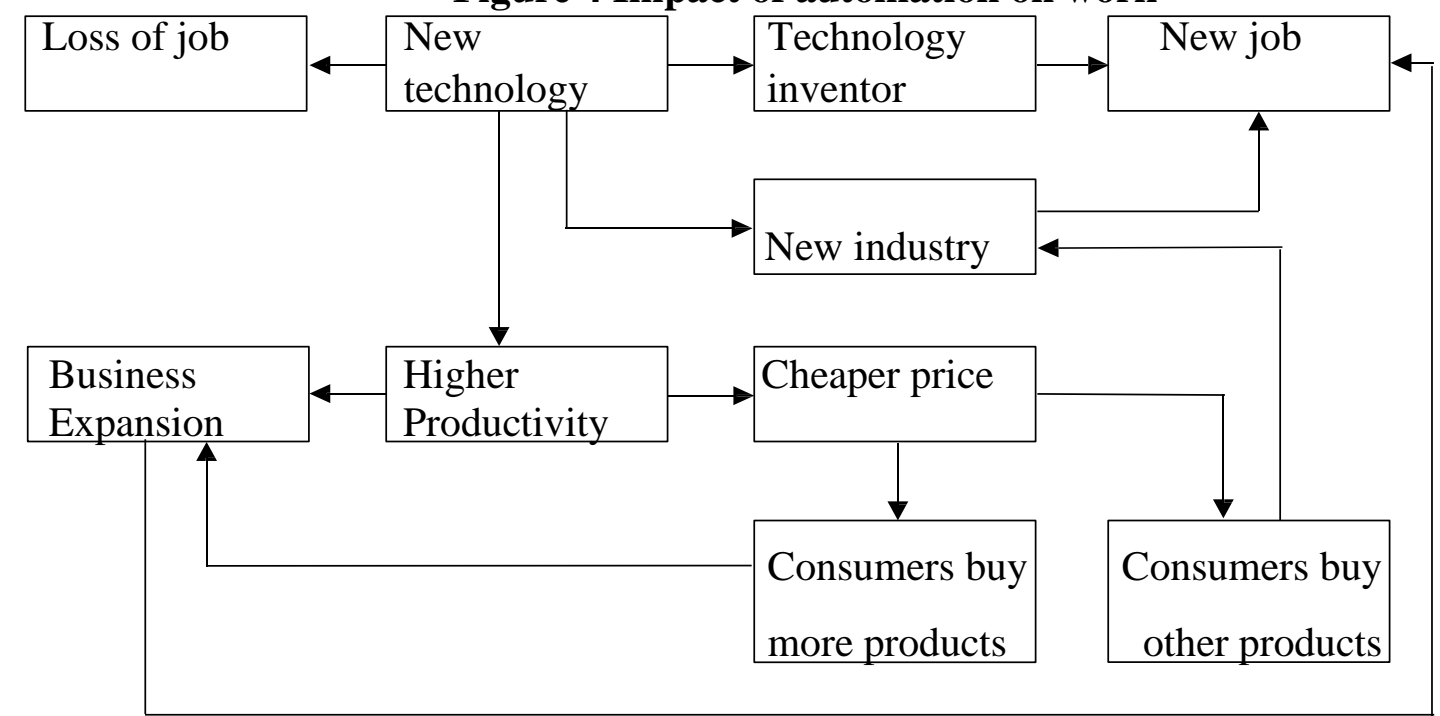

Source: Processed by the author

New technologies that are used as tools for automation will shift jobs that can be automated so that some workers lose their jobs. On the other hand, this technology will create a new industry related to the development of the technology itself and the suppliers of the technology will get more orders. This causes a new demand for labour to meet the increase in demand. What many people often forget is the indirect effect of incentives to reduce human labour. Technology will increase the productivity of the industry so that business actors have the option to expand their business with new products or add their business locations or reduce product prices because of the cost efficiency of using technology. Business expansion will require new workers while cheaper product prices will have an impact on consumer consumption patterns. Consumers will have two choices for the cheaper product, buy more of the product or use the difference in the price of the product to buy another product. An increase in product demand occurs when consumers use the price difference to buy more so that business actors can expand if desired to meet the increase in demand. Purchases of other products will have an impact on increasing demand for other industries. This cycle continues and becomes a part of our life.

Automation reduces the scope of work that humans can do. From the schematic in Figure 4, it can be seen that there are several events that create new jobs but the author cannot be sure that these new jobs will continue to exist in various sectors, considering that automation can automate these new jobs in the future. From various existing studies, the most difficult jobs to automate are those related to humans that require empathy and human interaction such as therapists, psychologists, choreographers, singers, and salesmen. This is difficult if everyone works in only a few fields. However, there are some jobs that use automation as a human complement such as dentistry.

The results of studies conducted by several leading institutions or companies in the world cannot provide clear predictions about the impact of automation on work as indicated by the non-uniformity of the results provided. This is influenced by differences in perceptions of automation capabilities, benchmarks taken, and goals to be achieved. A study conducted by Frey and Osborne (2017), "The Future of Employment: How Suspectible are Jobs to Computerization?" provides a clear limitation that $47 \%$ percent of jobs can be automated only reflecting the capabilities of automation technology. This study does not attempt to estimate the acceleration of automation occurring and its overall effect on work. Likewise with other studies.

Predicting the automation that will actually happen is very difficult because it requires a lot of data and is likely to remain an uncertain outcome. This is because technological 


\section{EDUCORETAX}

Volume 1 No. 3, September 2021

developments cannot be measured and many studies fail to measure them. The history that happened also cannot give a good clue in predicting it. Levy and Nurname (2004) assessed the future of automation and stated that jobs such as driving on the road were extremely difficult tasks for computers. Now, self-driving cars have become one of the icons of the 4th Industrial Revolution and are widely used by truck drivers in the United States although they still need supervision from the driver. A study conducted by Reddy (2004) with the title Fifty years of progress in speech recognition concluded that human speech level recognition is the goal which is difficult to understand. Today, this technology has many applications in the 4th Industrial Revolution and continues to grow.

In understanding how difficult it is to predict technological capabilities, the authors use the number of microprocessor transistors used by computer processors, which doubles every two years, according to Moore's Law. Moore's Law is a perception by Moore, the co-founder of Intel, in 1965 which stated that the number of microprocessor transistors in processors doubled every two years and the cost of transistors on those processors halved. This reflects the ability of the processor to move exponentially. With the increasing capability of the processor, the more potential technology can be found. Predicting with this scenario becomes very difficult because exponential growth has a mathematically infinite continuous value. Humans have a tendency to think and predict linearly so it is difficult to "agree" with technology. In addition, with the massiveness of the existing technology, by looking at the concept of AI in the machine learning section, the majority of existing smart technologies are still in the supervised learning category because humans still have dominant control in the learning process. It is something that cannot be imagined if all existing technologies are already in the unsupervised learning category. However, at each stage, there are limitations that will be experienced in technological renewal such as the material for which it is made.

Automation replacing humans whose work is automated is very obvious and unavoidable. What must be considered is whether the negative impact of automation can disrupt the economic situation and society in a country as a whole. If you look at the workers-topopulation ratio of the World Bank 2019, there was no serious spike overall but some countries are facing serious problems in the long term. This ratio needs to be combined with population demographic data in assessing the availability and lack of work because this ratio includes people who generally do not work such as elderly people.

China, Japan, and South Korea have good reasons why they continue to compete in the technology race, particularly in industrial robots. This is based on the unfavourable demographics of the population. Population growth in these countries is very low even Japan has a minus growth percentage. This problem is clearly stated in the background of each of these countries' robot strategies. In the New Robot Strategy, the Japanese Government stated that problems of plunging natality rate and aging population at a considerable pace globally. As a result Japan has to deal with such issues as declining productive-age population, lack of labour and high cost of social security.

In addition, these countries have a very high median age. From CIA World Fact Book 2020 data, these countries have a median age of over 38 years. Japan is the country with the second oldest median age after Monaco, followed by Germany which is also a big player in technology development and is the most automated country in Europe. Given the high median age and low population growth, it is predicted that these countries will be increasingly understaffed if no action is taken.

Indonesia has a high percentage of workers to population ratio based on data from the World Bank (2019). But keep in mind, this ratio counts workers regardless of decent work or not. Inappropriate work that does not require special skills is the main target of automation. Indonesia, like most developing countries, still has a very low quality of education. Since 2013, 


\section{EDUCORETAX}

Volume 1 No. 3, September 2021

Indonesia has had an education participation rate of 13-15 years above $90 \%$ according to the Central Statistics Agency in Education Indicators 1999-2019. However, from the 2018 PISA Score aimed at 15 years of age, Indonesia has always been in the lowest group for many years. year. Equality of education in Indonesia shows good performance but the quality provided is still very lacking. Education is often associated with a person's qualifications in getting a decent job. This makes the authors think that Indonesia is still not ready to face the Industrial Revolution 4.0 when compared to other countries. Massive automation can have serious repercussions if no proper policies are taken. Automation is a real thing and can change the dimensions of human work. The potential for automation remains something that cannot be predicted with certainty but every country needs to prepare and not be carried away by the existing conditions.

\section{Robot Tax and Its Challenges}

The automation does not only have an impact on workers whose work is automated but also on the government. Almost all countries carry out tax collection. One of the dominant types of taxes in state revenue is income tax obtained from the income of working and business people. When, workers earn income from their place of work or business, that income will be taxed. The income is then used to buy various needs and wants which can be subject to value added tax or other taxes based on the object of the tax. The purchase becomes income for the seller which is taxed with income tax. This shows that the more people move money or money equivalents, the more taxes the government gets. This event is called the butterfly effect in economics, where a small change has a multiplier effect. The occurrence of automation, makes some workers lose their jobs and the government also loses some of the potential taxes. Automation makes the circulation of money more limited because the costs incurred are less for business actors. Although this makes business actors incentivize to expand their business so that new transactions occur, the people involved mostly involve high-income people. Often, high-income people have a tendency to save most of their income in contrast to high-income people and low-income earners who use almost all of their income to make ends meet.

Apart from tax issues, automation causes income inequality. Jobs without special skills or skills will be less profitable because the value provided is less and automation provides many advantages over humans. On the other hand, skilled jobs will increasingly earn higher incomes as the advantages provided by automation shift the role of the unskilled workforce. In discussing income inequality, it is necessary to know how this inequality is measured. The Gini coefficient tends to only measure income inequality based on the nominal income earned. It does not reflect the value these people contribute to economic growth. This is because people who contribute more to the economy have a higher value so they deserve to earn high incomes.

On the other hand, people who make small contributions may get a small income as well. Without government intervention, economic inequality due to the industrial revolution is certain and the majority of economists agree with it, but the problem is how in which position this inequality has a bad effect on the country. Problems that may arise generally due to income inequality are access to education and health which becomes difficult, making those with low incomes even further left behind even though they have the potential to contribute more to their country. This is what often causes poverty that occurs often not because of their mistakes or "uselessness" but because of the country's system that keeps them poor.

The government has the responsibility to provide social and economic protection for its citizens so that the state and its citizens can continue to explore their ability to contribute and live prosperously. However, the government's source of income has the potential to be greatly reduced by automation and the increasing need for public protection in the face of automation. This made the government feel in a dilemma so that the idea of a robot tax emerged and became a debate for experts. 


\section{EDUCORETAX}

Volume 1 No. 3, September 2021

The author describes the robot tax as a government effort to carry out taxation aspects on automation robots and activities involving automation robots as a form of control in dealing with automation. The author argues that this is because the initiative in the form of a robot tax differs between Delvaux's proposal in the European Civil Law Rules on Robotics and the idea of a "robot tax" put forward by the President of South Korea in 2017. The European Civil Law Rules on Robotics provides a robot tax approach by making robots a legal person. so that it can become a tax subject while South Korea's "robot tax" is a form of reducing tax incentives on robot investment. The name robot tax came about because of the topic that became the culmination of the automation concerns brought about by Delvaux. Previous studies used by the author used the concept of lump-sum taxes imposed on business actors who use industrial robots.

South Korea's "robot tax" proposal has received little worldwide criticism. This is because what the President of South Korea wanted to do at that time was to reduce the level of tax incentives given to companies that actively invest in automation robots. Naming the robot tax is quite interesting because this initiative does not incur additional costs but only reduces the limit of the tax incentives provided. The government continues to incentivize companies to reduce their workforce through investment in automated robots. This proposal indirectly shows the government's formal acknowledgment that the massive automation that occurs in its country is starting to "eat" its tax revenues. With this proposal, the government hopes to implement a comprehensive public service and social welfare program.

The robot tax, which was introduced indirectly by Delvaux, received criticism from various parties because the definition of a robot he put forward was still too ambiguous. Delvaux defines smart autonomous robots as follows: "acquires autonomy through sensors and/or by exchanging data with its environment (inter-connectivity) and trades and analyses data; is self-learning (optional criterion); has a physical support; adapts its behaviours and actions to its environment."

There is still no general robot used by humans that can be called a smart autonomous robot. Most of the existing robots can be said to be "autonomous" but not yet "smart". The word "smart" in a general sense in society, indirectly indicates that robots are considered to be able to make their own decisions without being influenced by humans and can adapt themselves in various environments. This is important considering that giving electronic human status assumes that the robot is human and has rights that humans also have. The author in the previous discussion also stated that the existing AI system still uses a supervised learning system, which means that AI can do independent learning but humans still have full control over the AI. If it is analogous to human growth, the existing AI is still in the toddler stage (toddler). From the author's perspective, this concept is not impossible. However, by looking at the existing analogy, it is still too early and it seems like a "dream" to turn a robot into an electronic human because there are no robots that have complete capabilities like humans until now. The formation of a definition without the complete existence of the thing to be defined has the potential to lead to errors as described previously. In the world of criminology, there is a saying by William Blackstone that it is better for ten guilty people to run away than one innocent person to suffer.

In addition to the substance of the Delvaux proposal, the robot tax is considered to assess robotic innovation as a "catastrophe" and unethical. The author does not agree with this opinion. The author describes this tax as a double-edged sword, it can have positive and negative impacts depending on the tax system. In economics, there is a Laffer curve that shows the tax rate and state revenue. In this curve, taxes have a positive impact on rates resulting in the growth of tax revenues reaching a maximum point, then the tax rate showed a negative impact. When taxes show a positive impact on state revenues, people in general still carry out activities to increase 


\section{EDUCORETAX}

Volume 1 No. 3, September 2021

their income. This also shows the potential for public incentives with taxes to increase income so that they continue to receive income after deducting the desired tax to the optimal tax rate. This also applies to the robot tax. Business actors will consider whether the taxes that arise will still provide more benefits than using humans again. If business actors still feel that they are still getting benefits, business actors will continue to try to automate.

One important thing to be noted is that automation technology provides many advantages over humans. The government can also provide special incentives in several ways to maintain economic stability. Previous studies used by the author also show that the imposition of robot taxes still has a positive impact through mathematical tests on economic models. Nevertheless, the robot tax is considered suitable for countries that have been massively automated and feel the negative impact of such automation.

\section{Robot Tax Methods}

From the arguments that have been presented, the author argues that the robot tax is an acceptable thing. However, the income tax charged to the robot directly as a tax subject who can have the ability to pay his own tax is not yet possible for the author. The robot tax is now more likely to be imposed through business actors who carry out automation activities with automated robots. Therefore, in this section the author discusses several methods of taxation on robots that can be carried out in the current situation.

\section{A Reduction of Depreciation Expenses on Robot Automation}

Various countries generally provide incentives in the form of deductions in the form of depreciation costs that arise in correcting the residual value of their company's assets. Each country may have different rules for recognizing depreciation. The thing of concern is the method and time division of depreciation. In accounting, there are various methods of depreciation, namely the straight-line depreciation method, the declining balance depreciation method, the year number depreciation method, the working hour depreciation method, and the production unit depreciation method. Every business actor can select a favourable method for their business. Generally, the most desirable method is the method that can allocate a large depreciation expense at the beginning of the year which continues to decrease in value until the end of the year and in a short time. This relates to the concept of the time value of money. The amount of 100,000,000 rupiah in the present day will be more valuable than the same amount 3 years later. This matter is influenced by the concept of inflation where the value of the money will be increasingly worthless. The straight-line depreciation method provides the most favourable result for the government because the amount depreciated is the same every time. The greater the number of years of depreciation expense, the more cumulative burden embraced by business actors as a result of the concept of time value of money. The separation of robots from the category of general machinery and equipment is also a matter of concern, because automation robots are utilized to replace humans in the long term, so that they have a long-life use.

\section{Lump-Sum Taxes and Specific Taxes}

Lump-sum taxes and specific taxes are taxes levied based on the output produced. A lump sum tax is a tax levied on a certain amount regardless of the number of products produced. While the specific tax is a tax imposed with a certain amount on each unit of product. Both of these taxes can be imposed on production activities carried out by automation robots. The determination between lump-sum taxes and specific taxes is based on the objectives and behaviour of the market economy to be achieved. Lump-sum taxes are fixed costs for business actors, so that it will only affect the average cost curve, which shifts up while the marginal cost curve remains the same.

Figure 5 Graph of the impact of lump-sum taxes and specific taxes 


\section{EDUCORETAX}

Volume 1 No. 3, September 2021
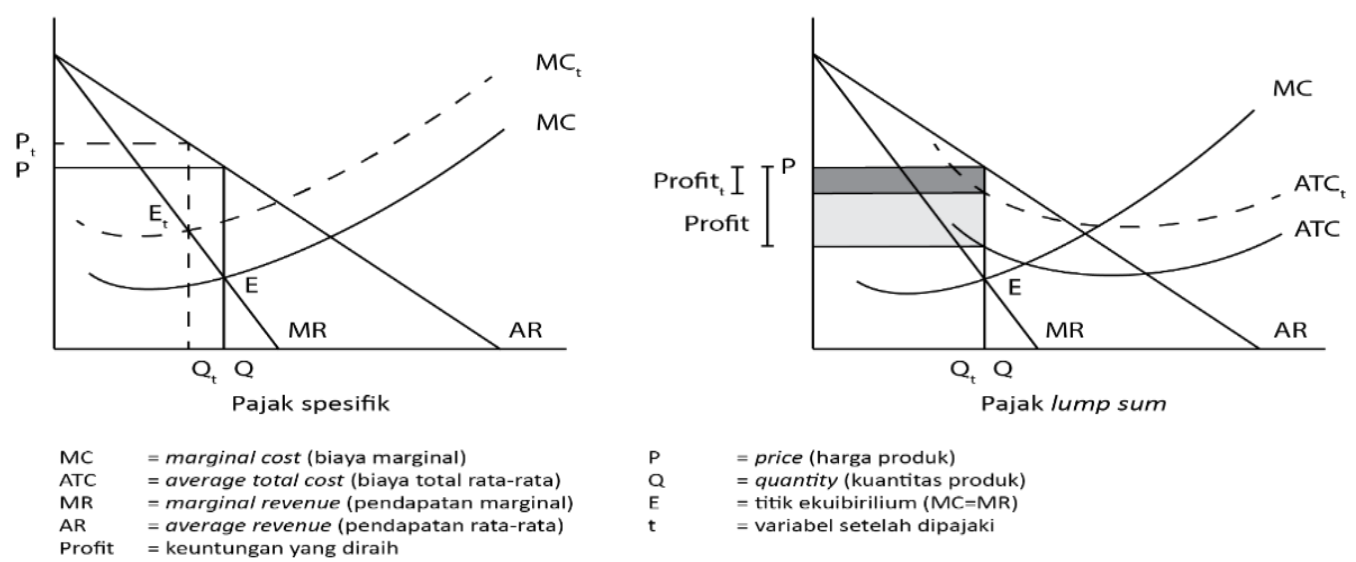

Source: Processed by the author

Specific taxes have characteristics such as variable costs for business actors. Thus, it will affect the average cost curve and the marginal cost curve, which shifts to the top right. Indirectly, the imposition of specific taxes makes robots work and are taxed like humans who are paid according to the quantity of products produced. Specific taxes can be taxed per unit (fixed rate per unit) or advalorem tax (percentage of unit price). With the right formulation and regulation, this tax can be a good choice for various countries in taxing automation robots.

On the other hand, lump-sum taxes provide different aspects from general taxes. When imposed on all subjects, lump-sum taxes will not interfere with the price ratio in the market and will not change economic decisions. However, the neutrality offered by lump-sum taxes does not make it very popular. The regressive characteristics of taxes often collide with aspects of ability to pay and fairness. Lump-sum taxes reflect tax neutrality at the expense of tax equity. It is considered to be suppressed by using lower limits such as lower income limits in its application. Another disadvantage of lump-sum taxes is that it sometimes requires a complete change of the tax system to meet the needs. Nevertheless, the neutrality of of lump-sum taxes is believed to be a safe solution when applied to robot automation.

\section{Elimination of Tax Incentives for Automating Work}

The author proposes reducing or eliminating incentives aimed at automating work, especially related to deductible loads. Abbot and Bogenschneider (2017) also propose various mechanisms to remove tax incentives in favour of automation. Corporate tax deductions can be discontinued for automation technology. This will eliminate the advantages that businesses get from automation which eliminates wage taxes, deduction timing, and indirect taxes. They also introduced an "automation tax" that could be based on the existing unemployment system. Businesses may be required to pay additional amounts into insurance plans if they perform automation at the expense of human workers. A corporate "entrepreneur" tax can be created for companies that rely on full automation. This would replace what the business entity would pay if it were staffed with human workers for whom it owed wage taxes. This would be the same as the self-employment tax paid by individuals, which would bring closer to the social security taxthat they would otherwise have to pay. This tax can be based on the ratio of the company's profit to gross employee compensation costs. Overall, these ideas are not a tax imposed on robots but rather the company is related to the automation activities it does.

\section{Other Solutions in the Face of Automation}

\section{Tax incentives on education and training activities for workers}

Tax incentives on education and training activities for workers is given to business actors who are active in providing training and education for their workers, especially in adapting themselves to automation. With this incentive, the cost of training and education for workers will be lower and it is hoped that it will provide incentives for business actors to conduct training and education because this can increase the productivity and capabilities of 


\section{EDUCORETAX}

Volume 1 No. 3, September 2021

workers. This incentive is also a stimulus for companies in managing their financial strategies, especially those related to taxes. This incentive is very suitable to be applied to countries that have low labour competence because it can attract many business actors, especially multinational companies to concentrate training and education in the country.

In Indonesia, this incentive has been accommodated by the government through Article 6 paragraph (1) letter $g$ of the Income Tax Law. The author recommends providing additional special incentives with an additional deduction of up to $25 \%$ of the cost of such education and training. Actually, additional incentives like this already exist in the form of Regulation of the Minister of Finance Number 128/PMK.010/2019 which provides additional incentives of up to $100 \%$ but this additional incentive is aimed at training and education participants who are not bound by a working relationship with any party. The author suggests that additional incentives are also needed, so that business actors have a tendency to improve the skills and expertise of their workers, especially with regard to developing the technology of automation compared to shifting existing workers. This can reduce layoffs which may occur.

\section{Tax incentives for donations to philanthropic institutions}

Tax incentives for donations to philanthropic institutions recognized by the government. Business actors, especially companies and people who have very high wealth can be conducted in some ways. High-income earners often use donations as a tool to save on taxes. Donation is a useful activity, but in many countries the regulation of tax incentives related to donations is still inadequate. There are many cases where business actors make donations in a special relationship or concentrate donations on those who provide special benefits to them so that the donations are of little benefit to the wider community. The narrowing of tax incentives to only donations made to social agencies or institutions recognized by the government or by increasing tax incentives on donations made to these entities or institutions provides encouragement to business actors in setting financial strategies so that the government and the wider community can still benefit from donations given. With this narrowing of incentives, the government is also expected to further expand the existing network of philanthropic institutions. This also indirectly encourages activities carried out by philanthropic institutions that are recognized by the government.

In Indonesia, this incentive has been accommodated through Article 6 paragraph (1) letters " $i$ " to " $m$ " of the Income Tax Law which is further regulated in a Minister of Finance Regulation. Number 76/PMK.03/2011. In the 2019 World Giving Index created by the Charity Aid Foundation, Indonesia is ranked 10th and is a major leader in the growth of this goodness index. The United States, Myanmar and New Zealand are the top 3 in this index. With the economic philosophy of gotong royong, it is hoped that donations will be able to help the government in providing maximum public services and facilities with friendly and targeted regulations.

\section{Tax incentives for Research \& Development activities}

Tax incentives for Research \& Development activities can also be imposed to stimulate research and development activities. These incentives have the same background as tax incentives for education and training. This incentive can have an offsetting effect from the imposition of taxes on automation robots. This incentive will encourage business actors to continue to innovate in their business. Furthermore, this incentive can be given to institutions or agencies that focus on technology development with higher rates so as to make the country a destination for research $\&$ development activities. This incentive is also very helpful for the government in providing research \& development facilities for the community through these institutions or agencies because the government in general cannot provide them.

In Indonesia, this incentive has also been regulated through Article 6 paragraph (1) letter $\mathrm{f}$ of the Income Tax Law. The author argues that this incentive can be given an additional up to 


\section{EDUCORETAX}

Volume 1 No. 3, September 2021

$100 \%$ or even $200 \%$. Incentive measures can also be regulated based on technology patents generated for activities in Indonesia. The government needs to provide the maximum possible support for research and development because so far research and development may be avoided because business actors want to avoid the risk of failure that occurs during these research and development activities. With additional incentives, the government provides protection for business actors conducting research and development activities. The author argues that the provision of additional incentives can be conducted by any countries and at any time that wants to become a leader in the field of research and development. According to Diestch (2015), the rate competition is relatively more profitable for those who cut their taxes from the beginning.

\section{Revision of indivual and corporate income tax rate}

The existing tax systems in various countries tend to be more profitable for business actors with very high incomes, especially the richest 5-10\% group. Existing taxes generally uphold the principle of quality as seen from the use of progressive rates. The principle which implies that everyone is taxed according to his or her ability does not apply to this very wealthy group. However, at this level, the relative tax burden actually decreased even lower than the poor. This happens because the existing tax does not tax capital but focuses on income. Rich people have a saving money habit, therefore generally there is no potential tax that comes after. On the other hand, although poor people in various countries are not subject to income tax at a certain level of income, they use all of their income to satisfy their needs subject to value added taxes (VAT). This tax contradicts the overall principle of equity. The existing tax system seems to strongly support income and wealth inequality. Therefore, it is necessary to adjust the income tax system by re-adjusting income groups, increasing the limit on income not subject to personal tax, and increasing rates for the highest income group and business entities. This policy is recommended to be applied to countries with high wealth inequality but with high level of tax compliance.

In 2020, the Indonesian Government had issued Omnibus Law on Tax Provisions and Facilities for Economic Strengthening as part of the Omnibus Law. This bill regulates various tax facilities aimed at attracting investment and supporting the economy in the long term. One of the points of this bill is the reduction in corporate income tax rates. The newest regulation is Tax Regulation Harmonization which has just been published in Law Number 7 Year 2021. In the bill, the corporate income tax rate will be to $22 \%$ starting from 2022 onwards. The author appreciates the government's steps with this policy but one point that needs to be considered for the author is that the government must improve the quality of its workforce to be more competent. One of the real impacts of this rate reduction is a decrease in tax revenue in the short term. The government should be more careful in managing its revenue redistribution strategy. Mistakes in strategy can affect the ineffectiveness of the benefits of economic change that are felt by the whole community. This policy also needs to be studied more deeply by experts.

\section{CONCLUSION}

\section{Conclusion}

Automation will shift the role of humans in jobs, because automation offers many advantages over humans. Automation not only makes some jobs escape humans, but also creates some new jobs. Question whether the impact of automation causes more jobs lost than jobs created or vice versa is still a matter of uncertainty. Studies conducted by various institutions are not able to predict the extent of the impact of automation can occur. The potential of automation technology is believed to be almost limitless and in an unpredictable space of time. This is proved by the failure of several studies that predict the ability of technology to "become" humans. In addition, by looking at data related to technology that is happening, it can be concluded that technology grows and develops exponentially. This 


\section{EDUCORETAX}

Volume 1 No. 3, September 2021

encourages the author to conclude that automation technology will one day shift human jobs more than new jobs created. Countries that support automation massively are countries that have limited manpower due to the aging population in that country.

The robot tax is one of the policies taken to reduce the pace of automation and provide time and financial opportunities for the government to provide public facilities needed by the community in facing automation. In addition, the robot tax is also intended to reduce income inequality that occurs and the tax revenue base that could potentially be lost due to automation. In assessing Delvaux's proposal, the author considers that the imposition of legal subject status on robots is still believed to be inappropriate because the definition still alludes to robots that are dependent on humans. The author also responds that the discourse of robot taxes, which is regarded as an inappreciated innovation is an incorrect statement, because robot taxes can create incentives for businesses to keep on developing their technology.

The author provides other alternatives in robot tax, namely: tax incentives on employee education and training activities, tax incentives on research activities and development, tax incentives on donations to recognized social institutions government, and readjustment of individual and corporate income tax rates. The first incentive may encourage business actors to provide education and training programs so that workers gain additional skills or expertise that are useful in dealing with automation. The second incentive can build technological innovation processes, create offsetting effects with robot taxes, and promote the country as a place for research and development. The third incentives aim to maximize the benefits of donations given to the wider community. The final incentive in readjustment of individual and corporate income tax rate should to be reformulated to reflect tax equity for all income layers and maximize tax revenue potential.

\section{Suggestion}

Based on the conclusion in the previous section, the author provides several suggestions regarding what has been discussed in this paper. Predicting the potential for technological advances is not an easy job, but the approach to predict is not an impossible action to do. Most studies have a weakness that has the same tendency, named the availability of data. The author suggests to governments in various countries to be more open in information sharing and statistics, which enable to provide comprehensive and in-depth data used by the general public in conducting research as a form of public participation in the state. The author also urges leaders in various countries to pay attention to the preparation of the community in facing automation, especially in the fields of education and health. The author also encourage to business and technology leaders not to forget to continue to provide benefits to the wider community through their efforts. Synergy actions from the government, business actors, and the community is needed in the sustainability of a country.

The author also suggests three recommendations in terms of robot taxes, namely setting deductible depreciation expenses, introducing taxes in the form of lump-sum taxes and specific taxes, and removing tax incentives that encourage automation. The deductible depreciation expense is based on the concept of the time value of money. The option between lump-sum taxes or specific taxes on automation robots is based on considerations in opting either quality or efficiency aspects in terms of the country's economy. The introduction of an "automation" tax can also be imposed on transition activities carried out by business actors. The "entrepreneur" tax is a tax option for business entities whose business activities are run entirely by automated robots.

\section{REFERENCES}

Abbott, R., \& Bogenschneider, B. (2018). Should robots pay taxes: Tax policy in the age of automation. Harv. L. \& Pol'y Rev., 12, 145. Guildford: University of Surrey 


\section{EDUCORETAX}

Volume 1 No. 3, September 2021

Agrawal, A., Gans, J., \& Goldfarb, A. (2018). Prediction machines: the simple economics of artificial intelligence. Harvard Business Press.

Charity Aid Foundation. (2019). CAF World Giving Index 10th Edition. Charity Aid Foundation.

CNBC Indonesia. (2019). Pejabat Eselon III-IV Bappenas yang Pertama Digantikan Robot. $\begin{array}{lllll}\text { November } 29 . & \text { Accessed } & 2019 .\end{array}$ https://www.cnbcindonesia.com/news/20191129130221-4-119040/pejabat- eselon-iiiiv-bappenas-yang-pertama-digantikan-robot.

Davis, N. (2016). What is the fourth industrial revolution? Januari 19. Accessed November 30, 2019. https://www.weforum.org/agenda/2016/01/what-is-the- fourth-industrialrevolution/.

Delvaux, M. (2017). Draft Report with Recommendations to the Commission on Civil Law Rules on Robotics. Brussels: European Parliament Committee on Legal Affairs.

Dunlop, T. (2017). What is a robot exactly - and how do we make it pay tax? Maret 13. Accessed November 29, 2019. https://www.theguardian.com/sustainablebusiness/2017/mar/13/what-is-a-robot-exactly-and-how-do-we-make-it-pay- tax.

Frey, C. B., \& Osborne, M. A. (2017). The future of employment: How susceptible are jobs to computerisation?. Technological forecasting and social change, 114, 254-280.

Gasteiger, E., \& Prettner, K. (2017). A note on automation, stagnation, and the implications of a robot tax. Discussion Paper, Berlin: Freie Universitat Berlin.

Gates, Bill, interview by Nikkei. (2018). 'Robot taxes' will help keep humans employed, Bill Gates predicts (November 3).

Gould, S. (2018). It took 75 years for the telephone to reach 100 million users... and it took Candy Crush Saga 15 months. Business Insider, 28 July 2015.

Iansiti, M., \& Lakhani, K. R. (2017). The Truth About Blockchain. Havard Buiness Review: January-February 2017, 118-127.

International Federation of Robotics. (2019). IFR World Robotics Presentation - 18 Sept 2019. Shanghai, September 18.

Jahanian, F. (2011). National Robotics Initiative. September. Accessed Juni 12, 2020. https://cra.org/crn/2011/09/national_robotics_initiative/.

Kim, S. M. (2018). Policy Directions for S. Korea's Robot Industry. Agustus 17. Accessed Juni 2, 2020. http://www.businesskorea.co.kr/news/articleView.html?idxno=24394.

Lakshminarayanan, A. (2019). Banking and the cloud: "Should banks adopt cloud computing solutions?" Oktober 11. Accessed Juni 2, 2020. https://bigdatamadesimple.com/banking-cloud-computing-solutions/.

Levy, F., \& Nurname, R. (2004). The New Division of Labor: How Computers Are Creating the Next Job Market. New York: Princeton University Press.

Lin, Z. (2017). Chinese Manufacturing Sector Rides Fourth Industrial Revolution Wave. Mei 5. Accessed November 2019. http://www.chinatoday.com.cn/english/economy/2017- 05/05/content_740124.htm.

Microsoft Azure. (2020). What is cloud computing? A beginner's guide. Accessed Juni 2, 2020. https://azure.microsoft.com/en-us/overview/what-is-cloud-computing/.

Miles, M. B., \& Huberman, A. M. (1994). Qualitative data analysis: An expanded sourcebook. London: SAGE Publications.

Mitchell, T. (1997). Machine Learning. New York: McGraw-Hill Education. Moravec, Hans P. 2020. Robot: Definition, History, Uses, Types, \& Facts. Juni 3. Accessed Juni 5, 2020. https://www.britannica.com/technology/robot- technology.

National Science Foundation. (2019). National Robotics Initiative 2.0: Ubiquitous Collaborative Robots. NSF 20-522, Virginia: National Science Foundation. 


\section{EDUCORETAX}

Volume 1 No. 3, September 2021

Nazir, M. (2014). Metode Penelitian. Bogor: Ghalia Indonesia.

Nevejans, N. (2016). European Civil Law Rules on Robotics. Study for The JURI Committee, Brussels: European Parliament.

OECD. (2014). Addressing the Tax Challenges of the Digital Economy, OECD/G20 Base Erosion and Profit Shifting Project. Accessed November 30, 2019. https://www.pmstax.com/intl/OECD-BEPS/BEPS_Digital_Economy_140916.pdf.

Olavsrud, T. (2013). How Cloud Computing Helps Cut Costs, Boost Profits. Maret 12. Accessed Juni 2, 2020. https://www.cio.com/article/2387672/how-cloud- computinghelps-cut-costs-boost-profits.html.

Pardes, A. (2020). The WIRED Guide to the Internet of Things. Februari 7. Accessed Juni 19, 2020. https://www.wired.com/story/wired-guide-internet- of-things/.

Pearlman, S. (2019). What is Internet of Things? Agustus 7. Accessed Juni 19, 2020. https://www.talend.com/resources/internet-of-things/.

Reddy, R. (2004). Fifty years of progress in speech recognition. The Journal of the Acoustical Society of America, 116(4), 2498-2498.

Reiff, N. (2020). Blockchain Explained. Februari 1. Accessed Juni 30, 2020. https://www.investopedia.com/terms/b/blockchain.asp.

Rosic, A. (2016). What is Blockchain Technology? A Step-by-Step Guide For Beginners. Accessed Juni 19, 2020. https://blockgeeks.com/guides/what-is- blockchaintechnology/.

Schwab, K. (2016). The Fourth Industrial Revolution: what it means, how to respond. Januari 14. Accessed November 28, 2019. https://www.weforum.org/agenda/2016/01/thefourth-industrial-revolution- what-it-means-and-how-to-respond/.

Sugiyono. (2015). Metode Penelitian Pendidikan Pendekatan Kuantitatif, Kualitatif, dan R\&D. Bandung: Alfabeta.

The Headquarters for Japan's Economic Revitalization. (2015). New Robot Strategy. Tokyo: Prime Minister's Office of Japan.

The Headquarters for Japan's Economic Revitalization. (2014). Japan Revitalization Strategy Revised in 2014. Tokyo: Prime Minister's Office of Japan.

The Headquarters for Japan's Economic Revitalization. (2015). Summary of Japan's Robot Strategy - It's vision, strategy and action plan. Tokyo: Prime Minister's Office of Japan.

Thuemmel, U. (2018). Optimal taxation of robots.

World Bank. (2019). World Development Indicators: Decent work and productive employment. Accessed Juni 20, 2020. http://wdi.worldbank.org/table/2.4.

Yanow, D. (2000). Conducting interpretive policy analysis (Vol. 47). SAGE Publications.

Yanow, D. (2007). Interpretation in policy analysis: On methods and practice. Critical policy analysis, 1(1), 110-122.

Yoon, S. W. (2017). Korea takes first step to introduce 'robot tax'. Agustus 7. Accessed Juni 28, 2020. https://www.koreatimes.co.kr/www/news/tech/2017/08/133_234312.html. 